\title{
使用荷重下における鉄筋コンクリート床スラブの 長期曲げ問題に対する解析法に関する研究
}

\author{
(第一報 ひび割れを生じた一方向スラブの瞬時曲げ問題に対する解析法) \\ STUDIES ON A METHOD OF ANALYSIS FOR LONG-TERM BENDINGS \\ IN REINFORCED CONCRETE SLABS UNDER SERVICE LOADS \\ (Part 1 The method of analysis for instantaneous bendings on one way \\ slabs after being cracked)
}

\author{
岩原昭次* \\ Teruji IWAHARA
}

\begin{abstract}
The method of analysis for long-term bendings have not been fully established in reinforced slabs under service loads. Even on instantaneous bendings, several problems for analysis on it have been remained unsolved partly though some methods for analysis which have effective work within relatively small deflection, several millimeters, have been proposed. The first reason of such a situation is that analytic treatments for slippage of tension steel at slab's edges is uncertain.

The final purpose of this studies is to estabilish a method of analysis on long-term bendings in reinforced concrete slabs, and as a part of studies and the first part, analytic treatments for slippage of tension steel is proposed, and an analytic method for instantaneous bendings considered slippage in one way slabs is shown.

The validity for this analytic method is investigated with previously published test data. Furthermore, by utilized those analysed results, several examinations are carried out.

The followed results is obtained.

(1) $\tau-s$ relation of bi-linear type proposed in this paper can be applied satisfactorily for the calculation of slippage of tension steel.

(2) The analytic method in consideration of slippage of tension steel in this pater suitably estimates instantaneous deflections and re-arrangement of stresses after being cracked.

(3) At least, the creation for allowable unit stress of tension steel for service loads has no effect for control of deflections or cracks on instantanous bendings of reinforced concrete slabs.

Keywords : reinforced concrete, one way slab, service load, instantaneous bendings, slippage of tension steel, analysis
\end{abstract}

§1.はじめに

$1-1:$ 研究目的

構造部材の長期曲げ問題に対する研究法の考え方とし て二つをあげることができる。一つは載荷直後（いわゆ る瞬時）から終局時に至る曲げ性状の経時履歴を追跡す る方法であり，もう一つは主として経時的に終局時の曲 げ性状にのみ着目する方法である。この二つの方法のう ち, 前者の観点に立つと, 鉄筋コンクリート（以下 RC と略）床スラブの長期曲げ問題に対する解析法は, 瞬時
曲げも含めて，まだ確立されているとはいい難い。

すなわち, 解析的に, 次の 3 項目をどのように定式的 に盛り込むか等, いくつかの小課題が末解决のままと なっている：(1)ひび割れ発生後における, 梁定着部（ス タブ) からのスラブ端部引張鉄筋の経時的な抜出しの評 価, (2)経時的なひび割れ発生の有り・無しの評価, (3)自 重, 積載荷重および施工荷重の経時的な荷重履歴の解析 への組入れ方法。

この中で, 特に, 第 1 の理由として上記の(1), すなわ 
ち,ひび割れ発生後における，スラブ端部引張鉄筋のス タブからの抜出しに対する解析的扱いが不明確であるこ とを挙げることができる。このため, 瞬時曲げ問題, 例 えば，瞬時たわみ等を取り上げてみても，これを解析的 に適切に評価できるまでには至っていないようである。

本研究の最終目的は RC 造床スラブの長期曲げ問題 に対する解析法を確立することにあるが，その一環とし て，また第一報として，前述した小課題(1)，(2)および(3) のうち，(1)のスラブ端部引張鉄筋の抜出しに対する解析 的扱いを提案し，また，これを考慮した一方向スラブの 瞬時曲げ問題に対する解析法を示す。そして，この解析 法の適合性を既往の実験資料で検討するとともに，この 計算結果を利用していくつかの考察を行う。

なお，以下の本文では，スタブからのスラブ端部引張 鉄筋の拔出しを, 単に,「鉄筋の抜出し」と略すること にする。

1-2：長期設計荷重下における既往の曲げ問題に対する

\section{解析法}

既往の研究ではすべてたわみに対して論じられている ので,このたわみに対する解析法について述べる。また， ここでは, 東 : 小森 ${ }^{1}$, 小柳ら ${ }^{21}$, 杉野目ら ${ }^{3)}$ おび ACI 435 委員会推奖 ${ }^{4}$ による各計算法について触れる。

東・小森は，たわみを部材部分の剛性によるたわみ $\delta_{0}($ (いゆる通常の計算による) と鉄筋の抜出しによる たわみ $\delta_{s}$ との和として計算する。この計算法は, ひび 割れ発生後の RC 部材に対する経時たわみは $\delta_{s}$ が無視 できないほど大きい要因であることを最初に示したもの で, その後のこの種の研究を方向付けたことで, 極めて 意義が大きい。しかしながら， $\delta_{s}$ は鉄筋の抜出し量 $s_{0}$ を

$$
s_{0}=\frac{\sigma_{s 0} g}{2 E_{s}} \quad\left(g=\frac{\sigma_{s 0} A_{s}}{\phi \tau_{a v}}\right)
$$

として計算し，また，スラブの端部と中央部間を剛体と 仮定して求めている。この計算法では, 既に論じた うに，長期設計荷重下における平均付着応力 $\tau_{a v}$ の扱い 方およびこれと $\tau-s$ 関係との関連について，また，た わみを $\delta_{0}$ と $\delta_{s}$ の単純和で表すことができるか等の解析 的なあいまいさを残している。

小柳らは，Mohr の定理に基づく共役梁法を，左右対 称荷重を受ける単一梁の弾塑性解析にうまく利用して, たわみ計算を行っている。両端固定一方向スラブに対し ては鉄筋の抜出しを考慮している。鉄筋の抜出し量 $s_{0}$ は片引き試験体に対する持続載荷実験から得られた実験 式を用い，これによる影響をスラブ端部での回転角で評 価する。小柳らの計算法では, ひび割れを生じる部材部 分の剛性をひび割れ剛性で評価するため, 経過日数 $t=$ 0 , すなわち, 瞬時たわみを含めて, 載荷時からある期 間までの経時たわみの進行を過大に見積る傾向がある。
また，鉄筋の抜出しに対する算定式は，片引き試験体に おける実験デー夕から得ているため, 当然ながら, 両引 き試験体の抜出しにモデル化できるような場合には適用 できない。

杉野目らは RC 造一方向スラブと二方向スラブの長 期たわみ計算法を発表している。二方向スラブに対して も基本的に同様なので，一方向スラブに対する計算法を 述べる。この計算法は, Branson の提案による有効断面 2 次モーメントを用いて, ひび割れ後の一方向スラブを 変断面梁に置換し，これに対し差分法により定式化する ものである。ひび割れ後の固定端においては東・小森と 同様な方法で鉄筋の抜出しを考慮する。解は，鉄筋の抜 出しを無視した場合の解と, この解での材端モーメント から算出した抜出しによる回転角を強制的に与えた場合 の解とを重称合わせ，これが収斂するまで反復計算を 行って求めようとするものである。しかしながら，抜出 しによる回転角を強制的に与えた場合の解は部材両端を 単純支持として定式化している点に解析上の問題を残し ている。

ACI 435 委員会推奨によるたわみ計算式は, 弾性たわ み計算式に準じるが，その際，断面 2 次モーメントとし て Branson の提案する有効断面 2 次モーメントで算定 する。この有効断面 2 次モーメント計算式は $2.2 \leqq$ $M_{\max } / M_{c} \leqq$ 約 4 および $1.3 \leqq I_{0} / I_{c} \leqq 3.5 （ M_{\max }$ : 弾性計

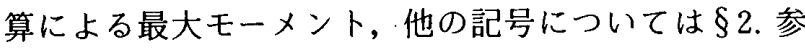
照）の範囲にある 54 体の試験体の実験結果を統計的に 整理して求められたものである6)。我が国の両端固定一 方向スラブの既往の実験資料によれば，長期たわみはも ちろんのこと, 瞬時たわみに対しても ACI 435 推奨式 は実験結果にあまり対応しないと考えられているようで ある。

\section{1-3：本研究における解析上の特徵}

本研究では, 他の既往の研究と同じように使用荷重レ ベルの載荷荷重を対象にした, 一方向床スラブの瞬時曲 げ問題に対する解析法を定式化する。この定式化にあ たって, 他の既往の研究と比較して特徴となる点は次の

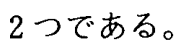

(1) 全ひずみ理論に立脚した弾塑性たわみ角式を誘導す る。付帯条件としてひび割れ条件が加わる。この式を用 いることの利点は, 問題を解くにあたって, 基本的には 通常のたわみ角法と同様な式展開を行うことである。し たがって, 既往の研究における共役梁法や差分法よりも 極めて応用範囲が広い。

なお, 弾塑性たわみ角式の誘導方法は, 山田の方法” とは異なるが, 考え方は同じである。

(2) スタブからの鉄筋の抜出しの影響を, $\tau-s$ 関係で の付着弾性剛性を用いて, 解析的に弾塑性たわみ角式の 中に組入れる。これによって，従来あいまいであった鉄 
筋の抜出し問題が解析的に解決できる。

\section{§2. 主な記号}

$\tau, \tau_{a v}, \tau_{\max }, \tau_{y}$ : 付着応力, 平均付着応力, 付着割裂強度, bi-linear 型 $\tau^{-} s$ 関係での付着強度

$s, s_{\max }, s_{0}$ : 相対滑り, 最大相対滑り量 $(0.3 \mathrm{~mm})$, 付 着試験体での加力端における相対滑り量（鉄 筋の抜出し量)

$E_{B}$ ：付着弾性剛性

$E, F_{c}, A_{q}$ : コンクリートのヤング係数, 圧縮強度, 有 効断面積

$E_{s}, \sigma_{y}, f_{t}, A_{s}$ : 鉄筋のヤング係数, 降伏点応力, 長期許 容応力度, 断面積

$n, p_{B}:$ そぞれ $E_{s} / E, A_{s} / A_{q}$

$\sigma_{s 0}$ : 付着試験体の加力端における鉄筋応力

$C_{\mathrm{min}}, D, \phi, g$ : 最小かぶり厚, 鉄筋直径, 鉄筋周長, 算 定用付着長

$I_{0}, I_{c}$ : 全断面およびひび割れ断面の断面 2 次モ一メ ント

$\alpha_{y}: I_{c} / I_{0}$

$l:$ 部材長

$a, b$ : 部材の左側の塑性域，右側の塑性域の長さ

$M, M_{x}, M_{0 x}$ : 曲げモーメント，部材の曲げモーメント分 布式，部材の両端を単純支持とした時の中間 荷重による曲げモーメント分布式

$M_{A B}, M_{B A}:$ 部材 $\mathrm{AB}$ 両端の材端モーメント

$M_{c}, M_{y}:$ ひび割れモーメント，降伏モーメント

$M_{c a}, M_{c b}$ ：塑性域 $a, b$ におけるひび割れモーメント

$G_{x}, F_{x}: M_{0 x}$ の 1 回および 2 回積分

$\lambda:$ 曲率

$u:$ 部材端部の引張鉄筋の抜出し量

$d, x_{n}:$ 有効丈, ひび割れ断面の中立軸

$\beta, X, \eta:$ れぞれ (9), (33), (34) 式

$K_{0}, K, k$ : 標準剛度, 剛度 $\left(I_{0} / l\right)$, 剛比

$\theta_{A}, \theta_{B}, R$ : 部材両端 $\mathrm{A}, \mathrm{B}$ の回転角, 部材の部材角

$\varphi_{A}, \varphi_{B}, \psi: \theta_{A}, \theta_{B}, R$ に関するパラメータ (26) 式

$\theta_{A}^{\prime}, \theta_{B}^{\prime}:$ 材端 $\mathrm{A}, \mathrm{B}$ に隣接するスタブの回転角

$\theta_{A}^{\prime \prime}, \theta_{B}^{\prime \prime}$ : 材端 A，Bにおける引張鉄筋の拔出しによる 回転角

$u_{i}, X_{i}$ : 材端AあるいはBにおける $u$ 之 $X$

$M_{i}, \theta_{i}, \theta_{i}^{\prime}, \theta_{i}^{\prime \prime}: M_{A B}$ あるいは $M_{B A}, \theta_{A}$ あるいは $\theta_{B}, \theta_{A}^{\prime}$ あ るいは $\theta_{B}^{\prime}, \theta_{A}^{\prime \prime}$ あいは $\theta_{B}^{\prime \prime}$

$M_{c i}, \beta_{i}$ : 塑性域 $a$ あるいは $b$ における $M_{c}$ と $\beta\left(\beta_{a}, \beta_{b}\right)$

\section{§3. 鉄筋の抜出し量算定式}

3-1：付着応力-滑り関係の提示

ここでは,ひび割れを生じるが降伏状態には至らない 設計荷重レベル, すなわち, 長期許容応力度以下の引張
鉄筋応力を対象とした $\tau-s$ 関係を数式表示する。

近年までの非常に多数の実験および解析資料の蓄積と 分析から， $\tau^{-} s$ 関係は，材料的要因や付着試験体の形 状の他に，鉄筋に沿って局所的に変化することが知られ ており，この関係を系統的に数式表示することは非常に 困難であるとされている8。しかしながら， RC 造骨組 のたわみ等の解析に対しては，スタブからの鉄筋の抜出 しを考慮する場合, 詳細な数式表示ではなく, むしろ, より合理的でかつ簡明に評価できる巨視的な $\tau-s$ 関係 の表示のほうが重要である。

以上の観点に立って， $\tau-s$ 関係を bi-linear 型と仮定 $し$, この場合の付着強度 $\tau_{y}$ と付着弾性剛性 $E_{\boldsymbol{s}}$ を以下 のように求める。

(1) $\tau^{-} s$ 関係の基本式として，六車・森田らが提案す る（2）式を用いる9!。

$$
\begin{aligned}
\tau_{x 1} & =e \frac{\log \left\{(e-1) s_{x 1}+1\right\}}{(e-1) s_{x 1}+1} \\
\tau_{x 1} & =\frac{\tau}{\tau_{\max }}, \quad s_{x 1}=\frac{s}{s_{\max }}
\end{aligned}
$$

ただし, $\tau_{\text {max }}$ は付着割裂強度, $s_{\text {max }}$ は最大相対滑り $(=$ $0.3 \mathrm{~mm}), \log$ は自然対数および $e$ は指数である。

bi-linear 型 $\tau-s$ 関係を (2) 式から定める。その際, bi-linear 型での $\tau_{y}$ は六車・森田ら ${ }^{9)}$ あいは鈴木・大野 ら ${ }^{10)}$ と同じように次式で表すことにする。

$$
\tau_{y}=0.9 \tau_{\max }
$$

また, 付着弾性剛性 $E_{B}$ は, 図一1に示すように, (2) 式による曲線（1）と bi-linear 型折線（2）で囲まれ る面積部分 $A_{1}$ と $A_{2}$ が等しくなるように定める。

結果として，次式が得られる。

$$
E_{B}=92.16 \tau_{\max } \text { あるいは } E_{B}=92.16\left(\frac{\tau_{y}}{0.9}\right) \cdots
$$

(2) $\mathrm{RC}$ 造スラブの配筋間隔は大きいので，もし付着割 裂破壊を起こすならば，スタブでの破壊のパターンは藤 井らが提案するV-notch splitになると考えられる11。 そこで， $\tau_{\max }$ として，付着割裂破壊をするような場合，

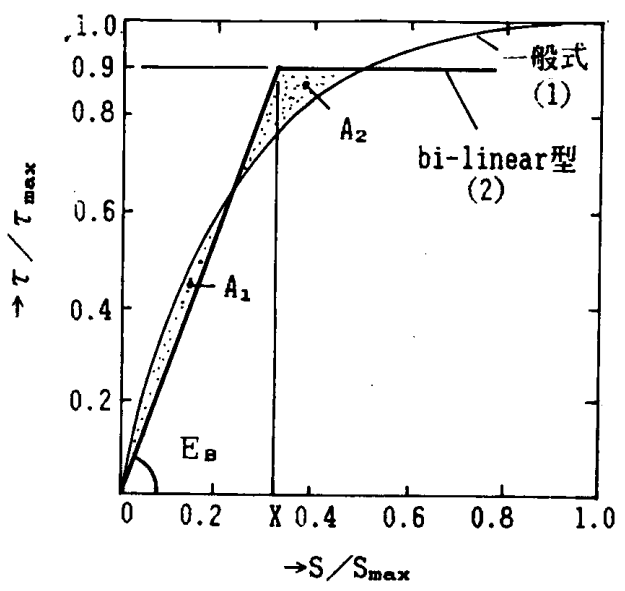

图一1 bi-linear 型 $\tau-s$ 関係 
藤井らが提案する V-notch 型付着割裂強度式 $(5)$ 式 を用いる。

$$
\begin{aligned}
& \tau_{\max }=\left(0.307 b_{i}+0.427\right) \sqrt{F_{c}} . \\
& b_{l}=\sqrt{3}\left(2 C_{\min } / D+1\right) \cdots \cdots \cdots .
\end{aligned}
$$

鉄筋とコンクリート間の付着性状を失うケースには, コンクリートの付着割裂破壊によるもののほかに，もう 一つ, 引張鉄筋の破断によるものがある。被り厚があり， 付着長が長い場合には大抵この破断に相当する。

この場合,

a. 村田らは実施した割裂引抜き試験で付着長を $8 D$ （鉄筋径 D 16～57）の場合コンクリートの破壊前 に鉄筋が破断することが多い(2)，また，小柳らは付 着長 $20 \mathrm{~cm}$ （鉄筋径 D 10 と 13）の片引き試験体は 鉄筋の降伏によって最終状態に達した ${ }^{131}$, と述べて いる。

b. 片引き試験体に対して, 解析的に有効な付着長は $35 D$ を用いれば十分である5!。

c. 最終時の付着応力は，コンクリートが割裂破壊し ないので,付着割裂強度よりも小さいと考えられる。

d. 加力端付近の引張鉄筋が降伏ひずみを超える場 合，鉄筋はかなりの伸び能力があるため，加力端か らある程度の深さまで塑性域になっていると推測さ れる。

等から総合的に判断して，次の仮定を設けて， $\tau_{y}$ を算 定することにする。

加力端の引張鉄筋の応力が $\sigma_{y}$ に達している状態にあ るとして, 付着長が $20 \mathrm{~cm}$ 以下の全域で完全塑性（ $\tau_{y}$

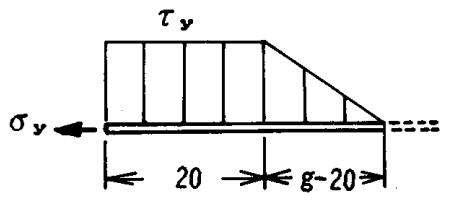

図-2 $\tau$ 分布の仮定
は一様分布）とし，付着長が $20 \mathrm{~cm}$ を超える場合，図 一2に示すように, $20 \mathrm{~cm}$ の長さ部分を完全塑性, 残り の $g-20(\mathrm{~cm})$ を弾性域とする。ただし， $g$ は $35 D$ を 超える時 $g=35 D$ とする。

この仮定より，次式を得る。

$$
\tau_{y}= \begin{cases}\frac{\sigma_{y} A_{s}}{(0.5 g+10) \phi} & (20 \leqq g \leqq 35 d) \\ \frac{\sigma_{y} A_{s}}{g \phi} & (g<20)\end{cases}
$$

以上の結果から, bi-linear 型 $\tau-s$ 関係を求める際の $\tau_{y}$ は（5) 式の $\tau_{\max }$ を（3）式に代入した值と（7） 式による值のうち，いずれか小さい方の値を採用する。

\section{3-2：鉄筋の抜出し量算定式の検討}

3-1 で提示した bi-linear 型 $\tau-s$ 関係の妥当性を，片 引き試験体あるいは片引き試験体とみなしてよい付着長 の長い兩引き試験体についての実験資料に対して検討し た。検討した試験体は六車・森田ら ${ }^{9 !}$ ，林ら ${ }^{14)}$ およ゙小 柳 ${ }^{13)}$ の実験資料によるものである。

図一 3 に鉄筋の拔出し量に対する計算結果亡実験結果 との比較を示す。本計算值は文献 5)で示した片引き試 験体に対する計算法によった。また，図中には，（1） 式による計算値および小柳による実験式 $\left(5 \sigma_{s 0} \times 10^{-3}\right.$ $\mathrm{mm})^{13)}$ も合わせて示してある。なお，最終值（十印） とあるのは，コンクリートが付着割裂強度あるいは鉄筋 が降伏点応力に達した時点を示す。

この図から，本計算結果は実験結果に比較的良く対応 することが分かる。弾性的とみなされる範囲内では，小 柳の提案式 $\left(5 \sigma_{s 0} \times 10^{-3} \mathrm{~mm}\right)$ も実験結果に良く対応す るようである。しかしながら（1）式については付着 長が短い場合 (例えば, FIII-70は付着長 $7 \mathrm{~cm}$ ) 実験結 果にあまり良く近似せず，また，最終值（図上十印）を 含めて，全体的に対応度にばらつきがある。

結局, 3 つの計算法の中で, 本論で提示した $\tau-s$ 関 係を用いる方法が全体的に実験

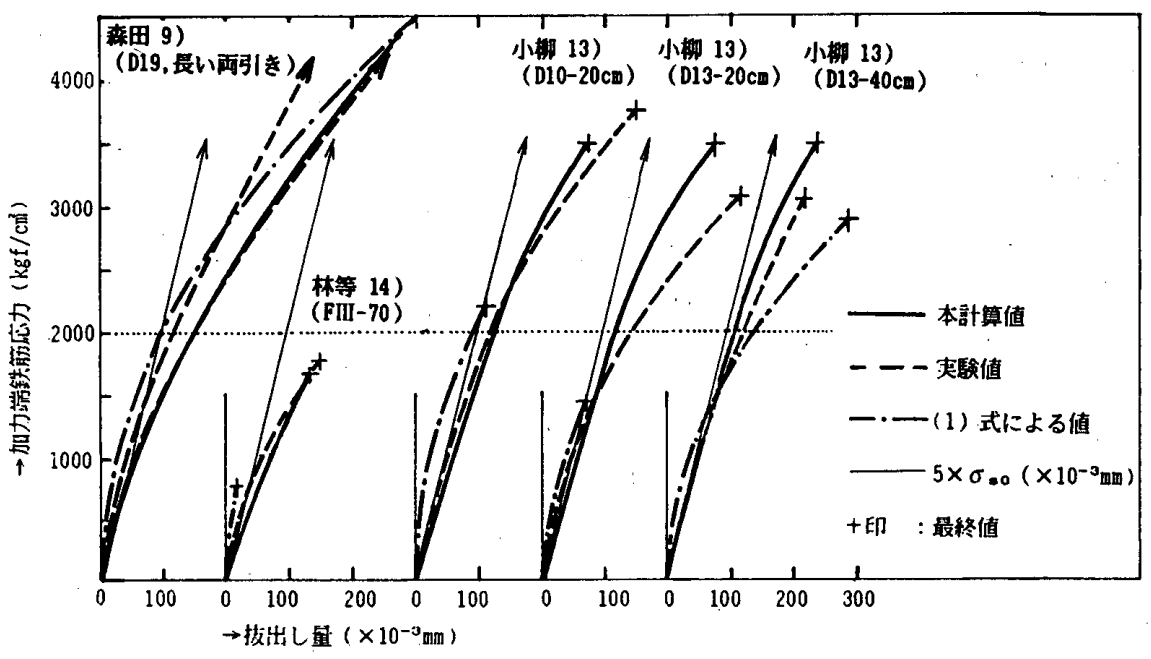

図一3 $\tau-s$ 関係式の妥当性に関する検討 結果に良く対応するということ がいえる。

また（1）式による方法と 小柳の提案式は, その誘導方法 からして，共に片引き試験体に モデル化できる鉄筋の抜出し問 題のみしか適用できないが，一 方，本論で提示した方法は付着 弾性剛性を求めているため，片 引き試験体のほかに，画引き試 験体にモデル化できるような場 合でも鉄筋の抜出し量を算定で きるという利点を有する。 


\section{§4. 瞬時曲げ問題に対する解析の定式化}

\section{$4-1:$ 基本式}

(1) 曲げモーメント-曲率関係

曲げモーメント-曲率関係 ( $M-\lambda$ 関係と略す) は, 図 -4に示すように, Tri-linear 型を仮定する。すなわち,

$$
\lambda= \begin{cases}\frac{M}{E I_{0}} & \left(0 \leqq M \leqq M_{c}\right) \\ \frac{M}{\alpha E I_{0}}=\frac{(1+\beta) M-\beta M_{c}}{E I_{0}} & \left(M_{c} \leqq M \leqq M_{y}\right)\end{cases}
$$

ただし，

$$
\begin{aligned}
& \beta=\frac{1 / \alpha_{y}-1}{1-M_{c} / M_{y}}, \quad \alpha_{y}=\frac{I_{c}}{I_{0}} \\
& M_{c}=1.8 \sqrt{F_{c}} \cdot Z \quad(Z=\text { 断面係数 }) \\
& M_{\mathbf{y}}=0.9 A_{s} \sigma_{y} d
\end{aligned}
$$

\section{（2）スタブにおける付着弾性剛性}

本解析では，既に述べたように，使用荷重下，すなわ ち，スラブ端部引張鉄筋に生じる応力がせいぜい長期許 容応力度程度以下となるような荷重レベルを対象とす る。このような荷重レベルでは, 付着剛性として付着弾 性剛性を解析に用いても十分である5)。ここでは $E_{B}((4)$ 式）を用いる。

\section{4-2：部材の弾塑性たわみ角式}

一般的な場合として，図一5(a) に示すような，両端 付近が塑性で，中央付近が弾性である部材を考える。た だし, 部材 $A B$ は, 弾性の場合, 均一の断面寸法を有 するとする。

曲げモーメント分布 $M_{x}$ は下側を正（+）とすると

$$
M_{x}=\frac{l-x}{l} M_{A B}-\frac{x}{l} M_{B A}+M_{0 x}
$$

ただし， $M_{0 x}$ は点 $A, B$ を単純支持とした時の中間荷 重による曲げモーメント分布を示す。

\section{（1）弾・塑性域におけるたわみとたわみ角の一般式} 区間 $\mathrm{A} \sim \mathrm{C}$ (塑性域)，CＤ（弾性域）および D B （塑性域）におけるたわみとたわみ角の一般式は次のよ うになる。ただし，区間 $\mathrm{A} \sim \mathrm{C}, \mathrm{C} \sim \mathrm{D}$ および $\mathrm{D} \sim \mathrm{B} に$

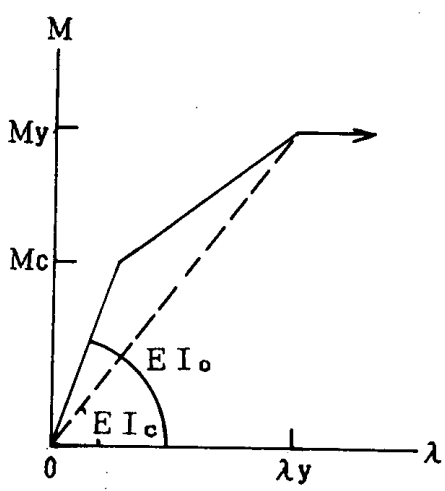

図一4 モーメントー曲率関係
関係するたわみ $y$ ，曲率入の記号にはそれぞれ添字 1 , 2, 3 を付ける。また，塑性域 $a$ あるいは $b$ に関係する $\beta, M_{c}$ の記号には $a, b$ の添字を付ける。

○区間 $\mathrm{A} \sim \mathrm{C}(0 \leqq x \leqq a)$

$$
\begin{aligned}
& \lambda_{1}=\frac{1}{E I_{0}}\left\{\left(1+\beta_{a}\right) M_{x}-\beta_{a} M_{c a}\right\} \\
& \frac{\partial^{2} y_{1}}{\partial x^{2}}=-\lambda_{1}
\end{aligned}
$$

の関係から，次式を得る。

$$
\begin{aligned}
E I_{0} \frac{\partial^{2} y_{1}}{\partial x^{2}}= & \left(1+\beta_{a}\right)\left(M_{A B}+M_{B A}\right) \frac{x^{2}}{l} \\
& \left.+1-\left(1+\beta_{a}\right) M_{A B}+\beta_{a} M_{c a}\right) x-\left(1+\beta_{a}\right) M_{0 x}
\end{aligned}
$$

上式を積分すると，次式を得る。

$$
\begin{aligned}
& E I_{0} \frac{\partial y_{1}}{\partial x}=\left(1+\beta_{a}\right)\left(M_{A B}+M_{B A}\right) \frac{x^{2}}{2 l} \\
& +1-\left(1+\beta_{a}\right) M_{A B}+\beta_{a} M_{c a} \mid x-\left(1+\beta_{a}\right) G_{x} \\
& +C_{1}
\end{aligned}
$$

$$
E I_{0} y_{1}=\left(1+\beta_{a}\right)\left(M_{A B}+M_{B A}\right) \frac{x^{3}}{6 l}
$$$$
+\frac{1}{2}\left\{-\left(1+\beta_{a}\right) M_{A B}+\beta_{a} M_{c a} \mid x^{2}+C_{1} x\right.
$$

ただし，$$
-\left(1+\beta_{a}\right) F_{x}+C_{2}
$$

$$
G_{x}=\int M_{0 x} d x, \quad F_{x}=\iint M_{0 x} d x d x
$$

（13）式と（14）式中の積分定数 $C_{1}, C_{2}$ のうち, 特に, $C_{2}$ は点 $\mathrm{A}, \mathrm{B}$ の鉛直方向変位を相対変位で表わすと, $x$ $=0$ で $y_{1}=0$ とすることができるので次式となる。

$$
C_{2}=\left(1+\beta_{a}\right) F_{0}
$$

○区間 $\mathrm{C} \sim \mathrm{D}(a \leqq x \leqq l-b)$

弾性範囲なので次式が得られる。

$$
E I_{0} \frac{\partial y_{2}}{\partial x}=\left(M_{A B}+M_{B A}\right) \frac{x^{2}}{2 l}-M_{A B} x-G_{x}+C_{3}
$$

$$
E I_{0} y_{2}=\left(M_{A B}+M_{B A}\right) \frac{x^{3}}{6 l}-\frac{1}{2} M_{A B} x^{2}+C_{3} x-F_{x}+C_{4}
$$

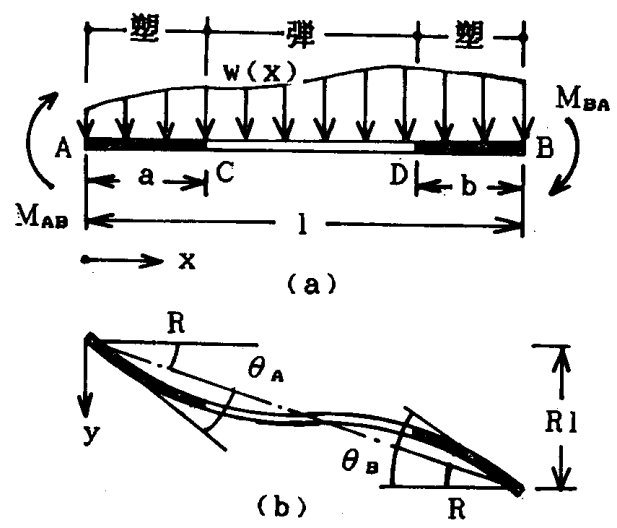

図一5 部材の弾塑性状態 
○区間 $\mathrm{D} \sim \mathrm{B}(l-b \leqq x \leqq l)$

(13)，(14）式と同一に誘導できて，次式となる。

$$
\begin{aligned}
E I_{0} \frac{\partial y_{3}}{\partial x}= & \left(1+\beta_{b}\right)\left(M_{A B}+M_{B A}\right) \frac{x^{2}}{2 l}-\left(1+\beta_{b}\right) M_{A B} x \\
& +\beta_{b} M_{C b} x-\left(1+\beta_{b}\right) G_{x}+C_{5} \cdots \cdots \cdots(19) \\
E I_{0} y_{3}= & \left(1+\beta_{b}\right)\left(M_{A B}+M_{B A}\right) \frac{x^{3}}{6 l}-\frac{1}{2}\left(1+\beta_{b}\right) M_{A B} x^{2} \\
& +\frac{1}{2} \beta_{b} M_{c b}\left(x^{2}-l^{2}\right)+C_{5}(x-l) \\
& -\left(1+\beta_{b}\right)\left(F_{x}-F_{l}\right)+\left(1+\beta_{b}\right)\left(2 M_{A B}-M_{B A}\right) \frac{l^{2}}{6} \\
& +E I_{0} R l \cdots \cdots \cdots \cdots \cdots \cdots \cdots \cdots \cdots \cdots \cdots(20)
\end{aligned}
$$

ただし，(20) 式は，部材 $A B$ の部材角を $R$ とし， $x$ $=l$ で $y_{3}=R l$ の条件を代入してある。

（2）弾塑性境界の連続条件と積分定数の決定

弾塑性境界域における連続条件は次のとおりである。

$$
\left.y_{1}\right|_{x=a}=\left.y_{2}\right|_{x=a}
$$

$$
\left.\frac{\partial y_{1}}{\partial x}\right|_{x=a}=\left.\frac{\partial y_{2}}{\partial x}\right|_{x=a} \text {. }
$$

$\left.y_{2}\right|_{x=l-b}=\left.y_{3}\right|_{x=l-b}$

$\left.\frac{\partial y_{2}}{\partial x}\right|_{x=l-b}=\left.\frac{\partial y_{3}}{\partial x}\right|_{x=l-b}$

積分定数 $C_{1}, C_{3}, C_{4}$ および $C_{5}$ は, (21) （24）式を 解くことによって求まる。

\section{（3）材端モーメントと節点角との関係式}

$M_{A B}, M_{B A}$ 之部材両端の回軸角 $\theta_{A}, \theta_{B}$ との関係は次式 から求まる。

$$
\left.\frac{\partial y_{1}}{\partial x}\right|_{x=0}=\theta_{A},\left.\quad \frac{\partial y_{3}}{\partial x}\right|_{x=l}=\theta_{B} \cdots \cdots \cdots \cdot(25 . \mathrm{a}, \mathrm{b})
$$

(14)，(20) 式を(25.a,b) 式に代入すると，結果と して，次の形に表すことができる。

$$
\begin{aligned}
& E I_{0} \theta_{A}=\frac{l}{3} A_{11} M_{A B}+\frac{l}{6} A_{12} M_{B A}+E I_{0} R+\frac{l}{6}\left(A_{13}+A_{14}\right) \\
& E I_{0} \theta_{B}=\frac{l}{6} A_{12} M_{A B}+\frac{l}{3} A_{22} M_{B A}+E I_{0} R+\frac{l}{6}\left(A_{23}+A_{24}\right) \\
& \text { 上式について } \\
& \left.\begin{array}{l}
k=K / K_{0}\left(K=I_{0} / l, K_{0}: \text { 標準剛度 }\right) \\
\varphi_{A}=2 E K_{0} \theta_{A} \quad \varphi_{B}=2 E K_{0} \theta_{B} \\
\psi=-2 E K_{0} R
\end{array}\right\} \cdots(26)
\end{aligned}
$$

とおき, $M_{A B}, M_{B A}$ で表すと次の関係式，すなわち，弾 塑性たわみ角式を得る。

$$
\left.\begin{array}{l}
M_{A B}=k\left\{J_{1} \varphi_{A}+J_{2} \varphi_{B}+\left(J_{1}+J_{2}\right) \varphi\right\}+J_{4} \\
M_{B A}=k\left\{J_{2} \varphi_{A}+J_{3} \varphi_{B}+\left(J_{2}+J_{3}\right) \varphi\right\}+J_{5}
\end{array}\right\}
$$

ただし，式中の諸記号は次のとおりである。

$$
\begin{aligned}
& V=\frac{1}{3}\left(4 A_{11} A_{22}-A_{12}^{2}\right) \\
& J_{1}=\frac{2 A_{22}}{V}, \quad J_{2}=-\frac{A_{12}}{V}, \quad J_{3}=\frac{2 A_{11}}{V} \\
& J_{4}=-\frac{1}{3}\left\{J_{1}\left(A_{13}+A_{14}\right)+J_{2}\left(A_{23}+A_{24}\right)\right\}
\end{aligned}
$$

$$
\begin{aligned}
J_{5}= & -\frac{1}{3}\left\{J_{2}\left(A_{13}+A_{14}\right)+J_{3}\left(A_{23}+A_{24}\right)\right\} \\
A_{11}= & +\frac{3 \beta_{a} a}{l}\left(1-\frac{a}{l}+\frac{a^{2}}{3 l^{2}}\right)+\frac{\beta_{b} b^{3}}{l^{3}} \\
A_{12}= & -\left\{1+\frac{\beta_{a} a^{2}}{l^{2}}\left(3-\frac{2 a}{l}\right)+\frac{\beta_{b} b^{2}}{l^{2}}\left(3-\frac{2 b}{l}\right)\right\} \\
A_{13}= & -\frac{6 \beta_{a} a}{l}\left(1-\frac{a}{2 l}\right) M_{c a}-\frac{\beta_{b} b^{2}}{l^{2}} M_{c b} \\
A_{14}= & -\frac{6}{l^{2}}\left(F_{0}-F_{l}+l G_{0}\right)+\frac{6 \beta_{a}}{l^{2}}\left\{F_{a}-F_{0}-l G_{0}\right. \\
& \left.+(l-a) G_{a}\right\}+\frac{6 \beta_{a}}{l^{2}}\left(F_{l}-F_{l-b}-b G_{l-b}\right) \\
A_{22}= & 1+\frac{\beta_{a} a^{3}}{l^{3}}+\frac{3 \beta_{b} b}{l}\left(1-\frac{b}{l}+\frac{b^{2}}{3 l^{2}}\right) \\
A_{23}= & \frac{3 \beta_{a} a^{2}}{l^{2}} M_{c a}+\frac{6 \beta_{b} b}{l}\left(1-\frac{b}{2}\right) M_{c b} \\
A_{24}= & -\frac{6}{l^{2}}\left(F_{0}-F_{l}+l G_{l}\right)-\frac{6 \beta_{a}}{l^{2}}\left(F_{0}-F_{a}+a G_{a}\right) \\
& \left.+\frac{6 \beta_{b}}{l^{2}} \mid F_{l}-F_{l-b}-l G_{l}+(l-b) G_{l-b}\right\}
\end{aligned}
$$

（4）荷重項 $G_{x}$ と $F_{x}$ について

スラブに対する使用荷重は, 通常, 集中荷重と等分布 荷重の 2 つが考えられる。ここでは，この 2 つの荷重の 扱い方について, 以下に示す。

○集中荷重に対して…集中荷重は, 中間荷重としてでは なく, 剛節点に加わる節点荷重として扱う。すなわち, $G_{x}=F_{x}=0$ 。

○等分布荷重に対して…等分布荷重 $w$ が加わる場合の 単純支持梁の曲げモーメント分布より次式となる。

$$
\left.\begin{array}{l}
G_{x}=\frac{w}{2}\left(-\frac{x^{3}}{3}+\frac{l}{2} x^{2}\right) \\
F_{x}=\frac{w}{2}\left(-\frac{x^{4}}{12}+\frac{l}{6} x^{3}\right)
\end{array}\right\}
$$

4-3：材端モーメントと鉄筋の抜出しによる回転角との 関係

\section{（1）スタブ部分のモデル化と回転角}

スラブとスタブとが接続している位置にひび割れが生 じた後のスタブ部分を，大きさが無視できる弾性的な長 方形パネルとする。またそのパネルの中心はスラブ端部 のひび割れ断面における中立軸上にあるとする（図一6 (a))。

部材材端の回転角を $\theta_{i}$, パネル部分の回転角を $\theta_{i}^{\prime}$ お よび鉄筋の抜出しによる回転角を $\theta_{i}^{\prime \prime}$ とし，また，鉄筋 の抜出し量を常に正 $(+)$ とすれば，次の関係が成立つ (図一6 $6(\mathrm{~b})$ )。

$$
\theta_{i}=\theta_{i}^{\prime}-\theta_{i}^{\prime \prime}
$$

上式の両辺に $2 E K_{0}$ を乗じ, $k=K / K_{0}((26)$ 式の第 1 式）を用いると次式を得る。 


$$
\varphi_{i}=\varphi_{i}^{\prime}-\frac{2 E I_{0}}{k l} \theta_{i}^{\prime \prime}
$$

ただし， $\varphi_{i}=2 E K_{0} \theta_{i}, \quad \varphi_{i}^{\prime}=2 E K \theta_{i}^{\prime}$

(2) 鉄筋の抜出し量とスラブ端部引張鉄筋応力

ひび割れ後の鉄筋の抜出し量 $u$ は, 付着試験体モデ ルでみると, 片引き形式のものと両引き形式のものの 2 つで評価することができる。前者はスタブの片側に, 後 者は両側に一方向スラブがある場合に相当する。

$$
u \text { を次式で表す。 }
$$

$$
u=X \sigma_{s} / E_{s}
$$

上式で， $X$ は， $\tau-s$ 関係に基づく付着弾性理論によ れば，ひび割れ後のスタブが片引き形式でモデル化でき る時 (33.a) 式で, 両引き形式でモデル化できる時 (33.b) 式となる5!。

$$
X= \begin{cases}\frac{\cosh \eta g+n p_{B}}{\eta \sinh \eta g} & \text { (片引き形式 }) \cdots(33 . \mathrm{a}) \\ \frac{\cosh \eta g-1}{\eta \sinh \eta g} & \text { (両引き形式 }) \cdots(33 . \mathrm{b})\end{cases}
$$$$
\text { ただし， }
$$

$$
\eta=\sqrt{\frac{1+n p_{B}}{E_{s} A_{s}} \phi E_{B}}
$$

なお，鉄筋比 $p_{B}\left(=A_{s} / A_{g}\right)$ 中のコンクリートの有 効断面積 $A_{g}$ は六車・森田ら ${ }^{15)}$ に代表されるように，図 一7に示すハッチ部分とする。

（3）材端モーメントと $u$ による回転角との関係

部材端部 $i$ でひび割れが生じているとすると，その位 置における曲率 $\lambda_{i}$ と材端モーメント $M_{i}$ との間には ( 8 ) 式の第 2 式と同様に次式となる。

$$
\lambda_{i}=\frac{1}{E I_{0}}\left\{\left(1+\beta_{i}\right) M_{i}-\beta_{i} M_{c i}\right\}
$$

ただし， $\beta_{i}=\frac{1 / \alpha_{y i}-1}{1-M_{c i} / M_{y i}}$

ここで，記号 $i$ は，図一5において，材端 $\mathrm{A}$ あるいは Bを表す。

引張鉄筋灾力 $\sigma_{s i}$ は
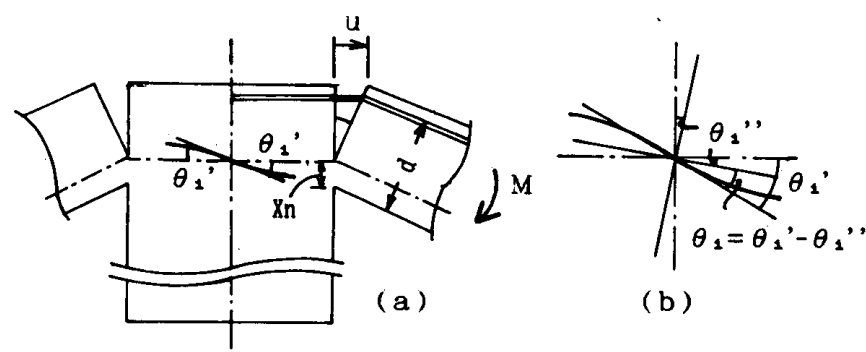

図一6 スタブにおける回転角

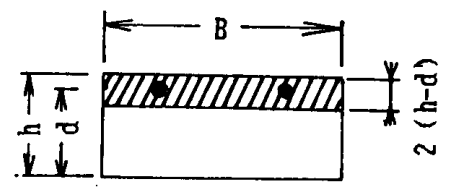

図-7 有効断面積

$$
\sigma_{s i}=E_{s} \lambda_{i}\left(d-x_{n}\right)
$$

上式と（35）式を（32）式に代入すると次式を得る。

$$
u_{i}=\frac{X_{i}\left(d-x_{n}\right)}{E I_{0}}\left\{\left(1+\beta_{i}\right) M_{i}-\beta_{i} M_{c i}\right\}
$$

一方，鉄筋の抜出しによる回転角 $\theta_{i}^{\prime \prime}$ を次式で表す（図 $-6(\mathrm{a}))$ 。

$$
\theta_{i}^{\prime \prime}=\frac{u_{i}}{d-x_{n}}
$$

(37) 式と（38）式を（31）式に代入すると次式を得る。

$$
\varphi_{i}=\varphi_{i}^{\prime}-\frac{2 X_{i}}{k l}\left\{\left(1+\beta_{i}\right) M_{i}-\beta_{i} M_{c i}\right\}
$$

4-4：鉄筋の抜出しを考慮した弾塑性たわみ角式

(1) 一般式

部材 $A B$ の両材端の回転角は（39）式より次式で表 示できる。

$$
\left.\begin{array}{l}
\varphi_{A}=\varphi_{A}^{\prime}-\frac{2 X_{A}}{k l}\left\{\left(1+\beta_{a}\right) M_{A B}-\beta_{a} M_{c a}\right\} \\
\varphi_{B}=\varphi_{B}^{\prime}-\frac{2 X_{B}}{k l}\left\{\left(1+\beta_{b}\right) M_{B A}-\beta_{b} M_{c b}\right\}
\end{array}\right\} \cdots(40 . \mathrm{a}, \mathrm{b})
$$

上式を $(27 . \mathrm{a}, \mathrm{b})$ 式に代入して整理すると，鉄筋の 抜出しを考慮した弾塑性たわみ角式として次式を得る。

$$
\left.\begin{array}{l}
M_{A B}=k\left(J_{1}^{\prime} \varphi_{A}^{\prime}+J_{2}^{\prime} \varphi_{B}^{\prime}+J_{3}^{\prime} \psi\right)+J_{4}^{\prime} \\
M_{B A}=k\left(J_{5}^{\prime} \varphi_{A}^{\prime}+J_{6}^{\prime} \varphi_{B}^{\prime}+J_{7}^{\prime} \psi\right)+J_{8}^{\prime}
\end{array}\right\}
$$
ただし，

$$
\begin{aligned}
J_{1}^{\prime}= & \left(B_{22} J_{1}-B_{12} J_{2}\right) / U \\
J_{2}^{\prime}= & \left(B_{22} J_{2}-B_{12} J_{3}\right) / U \\
J_{3}^{\prime}= & \left\{B_{22}\left(J_{1}+J_{2}\right)+B_{12}\left(J_{2}+J_{3}\right)\right\} / U \\
J_{4}^{\prime}= & \frac{1}{U}\left\{\frac { 2 } { l } \left[X_{A} \beta_{a}\left(B_{22} J_{1}-B_{12} J_{2}\right) M_{c a}\right.\right. \\
& \left.+X_{B} \beta_{b}\left(B_{22} J_{2}-B_{12} J_{3}\right) M_{c b}\right] \\
& \left.+B_{22} J_{4}-B_{12} J_{5}\right\} \\
J_{5}^{\prime}= & \left(-B_{21} J_{1}+B_{11} J_{2}\right) / U \\
J_{6}^{\prime}= & \left(-B_{21} J_{2}+B_{11} J_{3}\right) / U \\
J_{7}^{\prime}= & \left.1-B_{21}\left(J_{1}+J_{2}\right)+B_{11}\left(J_{2}+J_{3}\right)\right\} / U \\
J_{8}^{\prime}= & \frac{1}{U}\left\{\frac { 2 } { l } \left[X_{A} \beta_{a}\left(-B_{21} J_{1}+B_{11} J_{2}\right) M_{c a}\right.\right. \\
& \left.+X_{B} \beta_{b}\left(-B_{21} J_{2}+B_{11} J_{3}\right) M_{c b}\right] \\
& \left.-B_{21} J_{4}+B_{11} J_{5}\right\} \\
U= & B_{11} B_{22}-B_{12} B_{21} \\
B_{11}= & 1+2 X_{A} J_{1}\left(1+\beta_{a}\right) / l \\
B_{12}= & 2 X_{B} J_{2}\left(1+\beta_{b}\right) / l \\
B_{21}= & 2 X_{A} J_{2}\left(1+\beta_{a}\right) / l \\
B_{22}= & 1+2 X_{B} J_{3}\left(1+\beta_{b}\right) / l \\
&
\end{aligned}
$$

（2）種々の弾塑性域に対するパラメータの扱い

鉄筋の抜出しを考慮した部材の弾塑性状態しして, 表 -1に示す 5 ケースが考えられる。また，これに対応す る $(41 . \mathrm{a}, \mathrm{b})$ 式のパラメータの值を表-1 中に示す。 もし，鉄筋の抜出しを無視する場合には，X⿻あるい 


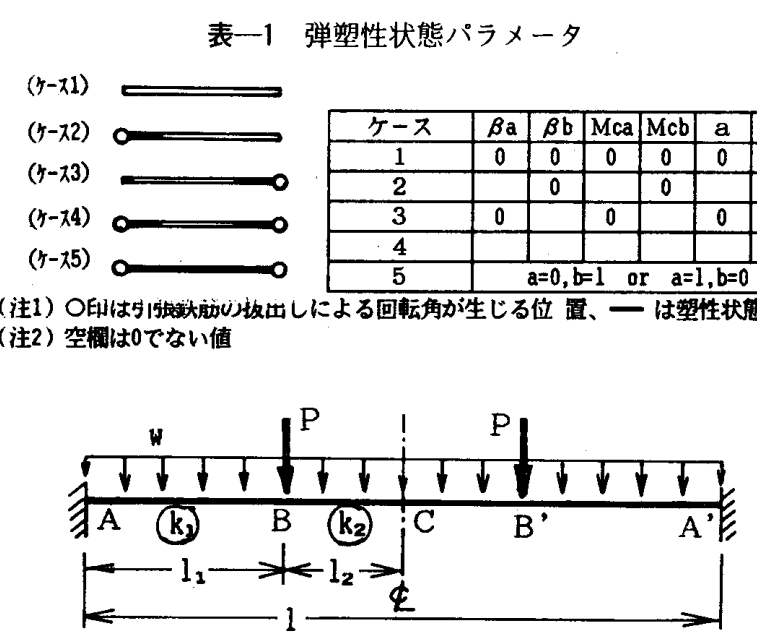

図一8 荷重状態とスラブ形状

は $X_{B}$ を 0 とすればよい。

4-5：ひび割れ条件

ひび割れ条件とは，図一5に示すような弾塑性部材に おいて, 弾塑性境界位置 $x=a$ あるいは $x=l-b$ でそ

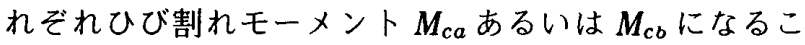
とをいう。すなわち，(10) 式より

$$
\left.\begin{array}{l}
M_{C a}=\frac{l-a}{l} M_{A B}-\frac{a}{l} M_{B A}+M_{0 a} \\
M_{C b}=\frac{b}{l} M_{A B}-\frac{l-b}{l} M_{B A}+M_{0 l-b}
\end{array}\right\} \cdots(42 . \mathrm{a}, \mathrm{b})
$$

ここでは， $a$ または $b$ は Newton-Raphson 法を用い て求めることにする。

\section{§5. 既往の実験資料による両端固定一方向スラブの瞬} 時たわみについて

載荷によってひび割れを生じる両端固定一方向スラブ に対して (41.a,b) 式を用いて解を求め, 既往の実験 資料における瞬時たわみの実験値と計算値を比較する。

通常, 両端固定一方向スラブの載荷状態は, 2 点対称 集中荷重と等分布荷重との組合せた荷重であるので，こ こでは，このような組合せ荷重に対して解を誘導する。 5-1：等分布と 2 点対称集中荷重を受ける両端固定一方

向スラブの解

図一 8 に示すような問題の解は, 対称条件から左半分 について，通常のたわみ角法の解法之同様に，末知数を $\phi_{B}^{\prime}, \psi_{A B}, \psi_{B C}$ として, 節点 Bで節点方程式を, 節点 B と Cで層方程式を立てることによって，求めることができ る。

すなわち，弾塑性たわみ角式を

$$
\begin{aligned}
& M_{A B}=k_{1}\left(J_{12}^{\prime} \varphi_{B}^{\prime}+J_{13}^{\prime} \psi_{A B}\right)+J_{14}^{\prime} \\
& M_{B A}=k_{1}\left(J_{16}^{\prime} \varphi_{B}^{\prime}+J_{17}^{\prime} \psi_{A B}\right)+J_{18}^{\prime} \\
& M_{B C}=k_{2}\left(J_{21}^{\prime} \varphi_{B}^{\prime}+J_{23}^{\prime} \psi_{B C}\right)+J_{24}^{\prime} \\
& M_{C B}=k_{2}\left(J_{25}^{\prime} \varphi_{B}^{\prime}+J_{27}^{\prime} \psi_{B C}\right)+J_{28}^{\prime}
\end{aligned}
$$

$$
\begin{aligned}
& \left(k_{1} J_{16}^{\prime}+k_{2} J_{21}^{\prime}\right) \varphi_{B}^{\prime}+k_{1} J_{17}^{\prime} \psi_{A B}+k_{2} J_{23}^{\prime} \psi_{B C} \\
= & -\left(J_{18}^{\prime}+J_{24}^{\prime}\right) \\
\{- & \left.k_{1}\left(J_{12}^{\prime}+J_{16}^{\prime}\right) l_{2}+k_{2}\left(J_{21}^{\prime}+J_{25}^{\prime}\right) l_{1}\right\} \varphi_{B}^{\prime} \\
& -k_{1}\left(J_{13}^{\prime}+J_{17}^{\prime}\right) l_{2} \psi_{A B}+k_{2}\left(J_{23}^{\prime}+J_{27}^{\prime}\right) l_{1} \psi_{B C} \\
= & p l_{1} l_{2}+w\left(l_{1}+l_{2}\right) l_{1} l_{2} / 2+\left(J_{14}^{\prime}+J_{18}^{\prime}\right) l_{2} \\
& -\left(J_{24}^{\prime}+J_{28}^{\prime}\right) l_{1} \\
& k_{2}\left(J_{21}^{\prime}+J_{25}^{\prime}\right) \varphi_{B}^{\prime}+k_{2}\left(J_{23}^{\prime}+J_{22}^{\prime}\right) \psi_{B C} \\
= & -w l_{2}^{2} / 2-\left(J_{24}^{\prime}+J_{28}^{\prime}\right)
\end{aligned}
$$

ひび割れ条件として,

$$
\left.\begin{array}{rl}
f_{1}\left(a_{1}\right)= & \left\{\left(l_{1}-a_{1}\right) M_{A B}-a_{1} M_{B A} / / l_{1}\right. \\
& +M_{01}\left(a_{1}\right)-M_{c 11}=0 \\
g_{1}\left(b_{3}\right)= & \left\{b_{1} M_{A B}-\left(l_{1}-b_{1}\right) M_{B A} / / l_{1}\right. \\
& +M_{01}\left(l_{1}-b_{2}\right)-M_{C 21}=0 \\
f_{2}\left(a_{2}\right)= & \left\{\left(l_{2}-a_{2}\right) M_{B C}-a_{2} M_{C B} / l_{2}\right. \\
& +M_{02}\left(a_{2}\right)-M_{c 12}=0 \\
g_{2}\left(b_{2}\right)= & \left\{b_{2} M_{B C}-\left(l_{2}-b_{2}\right) M_{C B} / / l_{2}\right. \\
& +M_{02}\left(l_{2}-b_{2}\right)-M_{C 22}=0
\end{array}\right\}
$$

より，次のような，Newton-Raphson 法を適用するため の漸近式を得る。

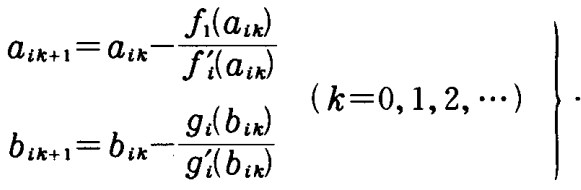

ただし， $a_{i}$ と $b_{i}(i=1,2): a_{1}$ と $b_{1}$ は部材 $\mathrm{AB}$ 左右 の, $a_{2}$ と $b_{2}$ は部材 $\mathrm{BC}$ 左右の塑性域の長さ。 $M_{01}, M_{02}$ : 部材 $\mathrm{AB}$ と $\mathrm{BC}$ の両端を単純支持とした場合の等分 布荷重による曲げモーメント分布式。 $M_{\mathrm{cl1}}, M_{\mathrm{c12}}$ ：部材 $\mathrm{AB}$ の左右材端のひび割れモーメント。 $M_{c 21}, M_{c 22}$ : 部 材 $\mathrm{BC}$ の左右材端のひび割れモーメント。

計算手順は次のとおりである。

(1) 初めに, 弾性解として (44) 式を解き, 曲げモーメ ント分布を求め, この分布から $a_{i}$ と $b_{i}$ を計算し, これ を初期値とする。

(2) 初期值をもとにして，再び (44) 式から $\varphi_{B}^{\prime}, \psi_{A B}$, $\psi_{\mathrm{BC}}$ を求め; これを $(45)$ 式に代入して $a_{i}$ と $b_{i}$ を計算 する。

(3) (2)の計算を $a_{i}$ と $b_{i}$ が収斂するまで絽り返す。

(4) $a_{t}$ と $b_{t}$ が収斂したならば，この繰り返しを打ち切 る。

この打ち切った時の $\varphi_{B}^{\prime}, \psi_{A B}, \psi_{B C}, a_{i}$ および $b_{i}$ が解とな る。次節 (5-2) で解析する試験体に対しては, 繰り返 し回数が 10 12 回程度で有効数字 8 析まで収斂した。 中央点（点C）のたわみ $\delta$ は $\psi_{A B}$ と $\psi_{B C}$ とから次のよ うに求まる。

$$
\delta=-\frac{1}{2 E K_{0}}\left(\psi_{A B} l_{1}+\psi_{B C} l_{2}\right)
$$


表一2 中央点たわみに対する計算値と実験值との比較

\begin{tabular}{|c|c|c|c|c|c|c|c|c|c|c|c|c|c|c|c|c|c|}
\hline 95 & 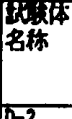 & 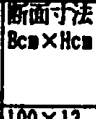 & $\begin{array}{l}\text { R八: } \\
\text { (cn) }\end{array}$ & 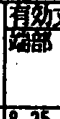 & (c) & 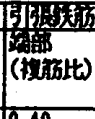 & 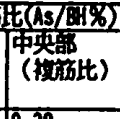 & 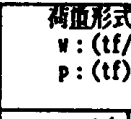 & & 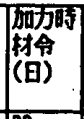 & 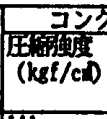 & 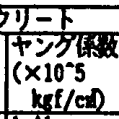 & 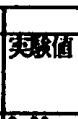 & 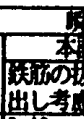 & 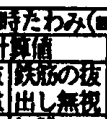 & 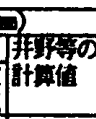 & 推 \\
\hline 要视 & $\left\{^{0-2}\right.$ & $100 \times 13$ & 360 & 8.35 & 10.5 & $\begin{array}{l}0.40 \\
(0.41)\end{array}$ & $\begin{array}{l}0.29 \\
0.94)\end{array}$ & \begin{tabular}{r|}
$\omega$ \\
$\cos 2 \sin$
\end{tabular} & $\begin{array}{l}E=0.312 \\
p=0.865\end{array}$ & 28 & 141 & 1.41 & 2.20 & $\begin{array}{l}\frac{10.96}{2.40} \\
(1.09)\end{array}$ & $\begin{array}{l}1.85 \\
(0.85)\end{array}$ & $=$ & 2.86 \\
\hline 侨苗 & 10.1 & $100 \times 14$ & 450 & 10.35 & 10.5 & $\begin{array}{l}0.45 \\
0.34) \\
0.34\end{array}$ & $\begin{array}{l}0.33 \\
(0.46)\end{array}$ & $P_{t}^{+}$ & $\begin{array}{l}P=0.536 \\
P=0.5175\end{array}$ & 28 & 179 & 1.84 & 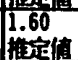 & $\begin{array}{l}\frac{12.00}{2.28} \\
(1.43)\end{array}$ & $\begin{array}{l}1.81 \\
(1.13)\end{array}$ & - & $\mid \begin{array}{l}2.98 \\
(1.86)\end{array}$ \\
\hline & $A-1$ & $100 \times 12$ & 380 & 9.5 & 9.5 & $\begin{array}{l}0.42 \\
0.72)\end{array}$ & $\begin{array}{l}0.30 \\
(0)\end{array}$ & & $p=0.576$ & 30 & 168 & 1.85 & 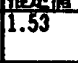 & $\begin{array}{l}1.63 \\
1.07) \\
(1.07\end{array}$ & $\begin{array}{l}1.30 \\
(0.85)\end{array}$ & 7.6 & $\begin{array}{l}2.44 \\
(1.59)\end{array}$ \\
\hline & $\mathbf{5 6}$ & $10 \times 13$ & 500 & 10.5 & 10.5 & $\begin{array}{l}0.49 \\
\text { (1) }\end{array}$ & $\begin{array}{l}0.49 \\
(0)\end{array}$ & croverto & $F=0.2496$ & 7 & 150 & 2.21 & 5.24 & $\begin{array}{l}5.77 \\
(1.10)\end{array}$ & $\begin{array}{l}4.23 \\
(0.81)\end{array}$ & $=$ & $\begin{array}{l}5.7 . \\
<1.0\end{array}$ \\
\hline & & & & & & & & & & 28 & 221 & 2.33 & 5.08 & 5.31 & 3.85 & $=$ & 4.95 \\
\hline $\ln$ & No.1 & $50 \times 12$ & 308 & 9 & 9 & $\begin{array}{l}0.36 \\
\text { (1) }\end{array}$ & $\begin{array}{l}0.36 \\
(0)\end{array}$ & $\frac{\operatorname{cosin}}{t}$ & $\begin{array}{l}P=0.144 \\
P=0.314\end{array}$ & 56 & 189 & 1.99 & 1.14 & $\begin{array}{l}1.001) \\
1.13 \\
(0.99)\end{array}$ & \begin{tabular}{|l}
$0.10)$ \\
0.91 \\
$(0.80)$
\end{tabular} & - & $\frac{0.98}{1.11}$ \\
\hline & No.2 & & & & & & & $P_{\psi} \psi^{p}$ & & 56 & 141 & 11.40 & 2.03 & 1.17 & 1.40 & - & 2.61 \\
\hline 21) & SN-1. & & 360 & 10 & 10.5 & $\begin{array}{l}0.35 \\
(1)\end{array}$ & $\begin{array}{l}0.35 \\
(0)\end{array}$ & & $F=0.430$ & 30 & 204 & 2.32 & 1.36 & 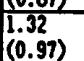 & $\begin{array}{l}\frac{.03)}{1.04} \\
(0.76)\end{array}$ & 9.1 & $\frac{1.04}{1.81}$ \\
\hline & SN-3 & $45 \times 13.5$ & & 12 & 10.2 & & & & $x=0.429$ & & & & 1.63 & (1.33 & 1.03 & 7.1 & 1.85 \\
\hline & $S:-4$ & $45 \times 13.3$ & & 8 & 10.1 & $\begin{array}{l}0.36 \\
\text { (i) }\end{array}$ & $\begin{array}{l}0.36 \\
(0)\end{array}$ & जनTासा | & $n=0.427$ & & & & 1.72 & $\begin{array}{l}1.002 \\
1.62 \\
(0.94)\end{array}$ & $\begin{array}{l}\frac{0.03}{1.30} \\
(0.76)\end{array}$ & 15.1 & 2.07 \\
\hline & SH-21 & $45 \times 13$ & 400 & 10 & 10.5 & {$\left[\begin{array}{l}0.37 \\
(1)\end{array}\right.$} & $\begin{array}{l}0.37 \\
(0)\end{array}$ & & $\pi=0.455$ & 29 & 202 & 2.17 & 4.47 & $\begin{array}{l}5.38 \\
(1.20)\end{array}$ & $\begin{array}{l}3.66 \\
(0.82)\end{array}$ & - & $\begin{array}{l}4.71 \\
(1.05)\end{array}$ \\
\hline & & & & & & & & & & & & & & $\begin{array}{l}5.38 \\
(1.00)\end{array}$ & $\begin{array}{l}3.66 \\
0.68)\end{array}$ & $=$ & 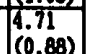 \\
\hline & & & & & & & & & $t=0$ & & & & 3.99 & $\begin{array}{l}3.49 \\
(0.87)\end{array}$ & $\begin{array}{l}2.32 \\
(0.58)\end{array}$ & & (o. \\
\hline
\end{tabular}

\section{5-2：瞬時たわみに対する実験値と計算值の比較}

既往の実験資料において, 載荷直後にひび割れを生じ た両端固定一方向スラブに対して解析を行う。瞬時たわ みについて実験値と本解析による計算値との比較を表 2 に示す沚1)。表一2 中には，鉄筋の抜出しを無視した場 合の計算値，杉野目らによる計算值 ${ }^{3)}$ およ゙ ACI 435 委 員会推奖式 ${ }^{4}$ による値も示してある。

鉄筋の抜出しを考慮した本解析値の実験值に対する比 は，中田の試験体（No.1）を除いて，0.82〜1.20であ る。特に，0.85〜1.15以内に収まるものが 12 体中 10 体あり，本解析值は実験値に良く近似する。

鉄筋の抜出しを無視した計算值は実験值に対して平均 で約 8 割弱の值となっている。また，その計算值が実験 値の約 6〜8 割程度しか評価していないものが 13 体中 4 体ある。

以上のことから, 変形が数 $\mathrm{mm}$ 程度の比較的小さい 瞬時たわみに対しても，ひび割れが生じたならば，鉄筋 の抜出しを考慮して計算を行う必要があることが分か る。

ACI 435 委員会推奨式による計算值は実験值の約 0.8 〜 1.6 倍であり，全体的にばらつきが大きい。実験値が 4 5 mm 程度だと, 計算值は実験值に比較的良く近似 するようである。このような比較的に良く近似する試験 体の $M_{\max } / M_{c}$ の值は大体約 2 に近い。

この比較の結果から，瞬時たわみに対する ACI 435 委員会推奨式は端部引張鉄筋の抜出しによる付加たわみ がある程度考慮されていると考えられ，それゆえ，瞬時 たわみが小さい場合付加たわみを大きく評価し，一方， ある程度以上の場合付加たわみを妥当に評価すると考え られる(12)。

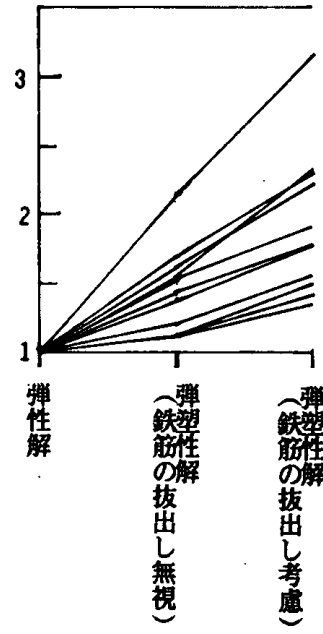

(a) 中央点たわみ

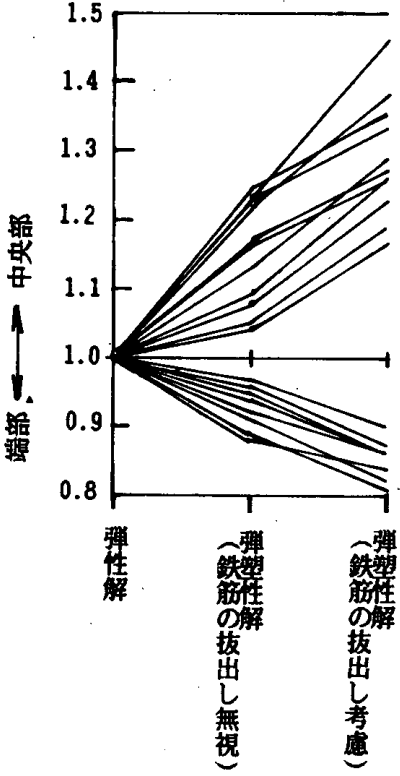

（b）端部と中央点モーメント
図一9 弾塑性解の弾性解に対する比率

5-3：解析結果についての考察

図-9に，表一 2 に載せた各試験体の中央点のたわみ, 端部亡中央点の曲げモーメントの弾性解, 鉄筋の抜出し を無視した場合の弾塑性解および考慮した場合の弾塑性 解の比較を示す。ただし，弾性解の值を基準（すなわち， 1)に表してある。また，解析結果から得られるひび割 れ発生状況で区分して, 弾塑性解の弾性解に対する比率 を示すと表一3のようになる。

図一9は，中央点たわみと端部モーメントが弾性解 $\rightarrow$ 鉄筋の抜出しを無視した弾塑性解 $\rightarrow$ 鉄筋の抜出しを考 慮した弾塑性解の順で, それぞれ, 大略, 直線状に増大 あるいは減少していく傾向を示している。

表一 3 から, 中央点のたわみについて, 鉄筋の抜出し 
表一3 ひび割れ発生状況による弾塑性解/弾性解（(）内は平均)

\begin{tabular}{|c|c|c|c|c|c|c|}
\hline \multirow{2}{*}{$\begin{array}{l}\text { ひびわれ発生状 } \\
\text { 況 }\end{array}$} & \multicolumn{2}{|c|}{ 中央たわみ } & \multicolumn{2}{|c|}{ 端部モーメント } & \multicolumn{2}{c|}{ 中央モーメント } \\
\cline { 2 - 7 } & 弾望性 & 拔出し & 弾塑性 & 技出し & 弾塑性 & 拔出し \\
\hline 端部のみ & $1.10 \sim 1.37$ & $1.36 \sim 1.78$ & $0.89 \sim 0.97$ & $0.81 \sim 0.90$ & $1.05 \sim 1.25$ & $1.17 \sim 1.46$ \\
\cline { 2 - 7 } & $(1.22)$ & $(1.54)$ & $(0.95)$ & $(0.87)$ & $(1.12)$ & $(1.28)$ \\
\hline 端部と中央部 & $1.52 \sim 2.15$ & $2.23 \sim 3.16$ & $0.87 \sim 0.94$ & $0.83 \sim 0.87$ & $1.10 \sim 1.23$ & $1.21 \sim 1.35$ \\
\cline { 2 - 7 } & $(1.71)$ & $(2.39)$ & $(0.91)$ & $(0.85)$ & $(1.18)$ & $(1.29)$ \\
\hline
\end{tabular}

表一4 $M_{e}, M_{d}$ および $\sigma_{s}$

\begin{tabular}{|c|c|c|c|c|c|c|c|c|c|c|}
\hline \multirow{3}{*}{$\begin{array}{l}\text { 研究 } \\
\text { 者名 }\end{array}$} & \multirow{3}{*}{$\begin{array}{l}\text { 試駼 } \\
\text { 体名 }\end{array}$} & \multicolumn{6}{|c|}{ 曲げモーメント（tfm） } & \multirow{3}{*}{$\begin{array}{l}\text { 解析的な中央 } \\
\text { 部のひびわれ } \\
\text { 発生の有無 }\end{array}$} & \multirow{3}{*}{$\begin{array}{l}\mathrm{Md} \\
(\operatorname{tfm})\end{array}$} & \multirow{3}{*}{$\begin{array}{c}\sigma s \\
\left(\mathrm{kgf} / \mathrm{cm}^{\wedge} 2\right)\end{array}$} \\
\hline & & \multicolumn{3}{|c|}{ 端部 } & \multicolumn{3}{|c|}{ 中央 } & & & \\
\hline & & 彈性 & 弾塑性 & 抜出し & 弾性 & 彈塑性 & 抜出し & & & \\
\hline \multirow{2}{*}{$\begin{array}{l}\text { 安丽 } \\
\text { 中田 }\end{array}$} & \multirow[t]{2}{*}{$D-2$} & 0.92 & 0.84 & 0.75 & 0.36 & 0.45 & 0.53 & \multirow[t]{2}{*}{ 無 } & \multirow[t]{2}{*}{0.80} & \multirow[t]{2}{*}{847} \\
\hline & & & $(0.91)$ & $(0.82)$ & & $(1.25)$ & $(1.46)$ & & & \\
\hline \multirow[t]{2}{*}{ 中田 } & \multirow[t]{2}{*}{ No.1 } & 1.00 & 0.97 & 0.94 & 0.43 & 0.46 & 0.53 & \multirow[t]{2}{*}{ 無 } & \multirow[t]{2}{*}{1.15} & \multirow[t]{2}{*}{677} \\
\hline & & & $(0.97)$ & $(0.90)$ & & $(1.07)$ & $(1.23)$ & & & \\
\hline \multirow[t]{2}{*}{ 松崎 } & \multirow[t]{2}{*}{$A-1$} & 0.69 & 0.67 & 0.63 & 0.35 & 0.37 & 0.41 & \multirow[t]{2}{*}{ 無 } & 0.83 & \multirow[t]{2}{*}{504} \\
\hline & & & $(0.97)$ & $(0.90)$ & & $(1.06)$ & $(1.19)$ & & & \\
\hline \multirow[t]{4}{*}{ 山本 } & \multirow[t]{2}{*}{ S6 } & 0.52 & 0.48 & 0.45 & 0.26 & 0.30 & 0.38 & \multirow[t]{2}{*}{ 有 } & \multirow[t]{4}{*}{0.47} & \multirow[t]{2}{*}{1280} \\
\hline & & & $(0.92)$ & $(0.87)$ & & (1.15) & $(1.26)$ & & & \\
\hline & \multirow[t]{2}{*}{ 57 } & 0.52 & 0.48 & 0.45 & 0.26 & 0.31 & 0.33 & \multirow[t]{2}{*}{ 有 } & & \multirow[t]{2}{*}{1232} \\
\hline & & & $(0.92)$ & $(0.87)$ & & $(1.19)$ & $(1.27)$ & & & \\
\hline 小楖 & NO.1 & 0.35 & 0.34 & 0.31 & 0.21 & 0.22 & 0.25 & 無 & 0.34 & 408 \\
\hline & & & $(0.97)$ & $(0.90)$ & & $(1.05)$ & $(1.17)$ & & & \\
\hline & NO.2 & 0.35 & 0.33 & 0.30 & 0.21 & 0.23 & 0.26 & 有 & & 719 \\
\hline & & & $(0.94)$ & $(0.86)$ & & $(1.10)$ & $(1.23)$ & & & \\
\hline 岩原 & SH-1 & 0.46 & 0.44 & 0.40 & 0.23 & 0.26 & 0.30 & 無 & 0.38 & 598 \\
\hline & & & $(0.96)$ & $(0.86)$ & & $(1.13)$ & $(1.29)$ & & & \\
\hline & SH-3 & 0.46 & 0.44 & 0.40 & 0.23 & 0.25 & 0.29 & 無 & 0.45 & 606 \\
\hline & & & $(0.96)$ & $(0.87)$ & & $(1.09)$ & $(1.26)$ & & & \\
\hline & SN-4 & 0.46 & 0.41 & 0.37 & 0.23 & 0.28 & 0.32 & 無 & 0.30 & 618 \\
\hline & & & $(0.89)$ & $(0.81)$ & & $(1.22)$ & $(1.38)$ & & & \\
\hline & SN-21 & 0.61 & 0.54 & 0.51 & 0.30 & 0.37 & 0.40 & 有 & 0.38 & 1859 \\
\hline & SN-22 & & $(0.89)$ & $(0.84)$ & & $(1.23)$ & $(1.33)$ & & & \\
\hline & SH-23 & 0.54 & 0.47 & 0.44 & 0.27 & 0.33 & 0.36 & 有 & & 1253 \\
\hline & & & $(0.89)$ & $(0.83)$ & & $(1.22)$ & $(1.35)$ & & & \\
\hline
\end{tabular}

（注1） 弾：弾性解

弾望性 : 弾塑性解 (鉄筋の抜出し無視) 抜出し：弾塑性解（铁胼の抜出し考慮）

（注2）（）内は弾性解に対する比率

（注3） Md：長期許容曲げモーメント

（注4） $\sigma \mathrm{s} ：$ 鉄筋の拔出しを考慮した端部モーメントによる引張铁筋応力

を考慮した弾塑性解值は，鉄筋の拔出しを無視した弾塑 性解値に対して，端部にのみひび割れを生じる場合平均 で約 1.3 倍（1.54/1.22），端部と中央にひび割れを生じ る場合平均で約 1.4 倍 (2.39/1.71) であり，たわみに 対して鉄筋の抜出しの影響がかなり大きいことが分か る。

また，端部モーメントと中央部モーメントについて， 鉄筋の抜出しを考慮した本解析解の弾性解に対する比率 はそれぞれ約 0.86 倍之約 1.29 倍を示しており，このこ とから，端部に生じるモーメントがひび割れモーメント 以上となる場合には端部でのひび割れ発生以後のモーメ ントはあまり増加せず，その分，中央部のモーメントが 増加し，中央部にもひび割れを誘発しやすくさせること が分かる。

表一4に引張鉄筋の抜出しを考慮した弾塑性解による 端部モーメント $M_{e}$, 長期許容曲げモーメント $M_{d}$ およ び $M_{e}$ から求めた端部引張鉄筋応力 $\sigma_{s}$ も合わせて示す。 この表から， $M_{e}$ は $M_{d}$ を大きく超える場合 $(\mathrm{SN}-21$,
$\mathrm{SN}-22)$ 長期許容応力度 $f_{t}=2 \mathrm{tf} / \mathrm{cm}^{2}$ 近 くなるが， $M_{e}$ が $M_{d}$ をや超える程度 以下ならば， $\sigma_{s}$ は $f_{t}$ よりもかなり低く なることが分かる。このことは，少なく とも，瞬時での床スラブに対する長期許 容応力度の設定はたわみやひび割れの制 御に余り寄与していないことを表してい る。

\section{§6. まとめ}

従来，比較的暧昧であった床スラブの 瞬時曲げ問題の計算法について, 特に, 一方向床スラブに対する定式化を行い， 既往の実験資料を解析的に検討した。次 のような結果を得た。

(1) 本論文で提示した bi-linear 型 $\tau-s$ 関係式は鉄筋の抜出し量算定に対して十 分適用できる。

(2) 引張鉄筋の抜出しを考慮した本解析 法はひび割れ発生後の瞬時たわみや応力 再配分を適切に評価する。

(3) 少なくとも，床スラブの瞬時曲げ問 題に対して, 鉄筋の長期許容応力度の設 定はたわみやひび割れ制御に余り寄与し ない。

\section{謝 辞}

本論文をまとめるにあたって, 京都大 学工学部建築学科助手 藤井 栄氏から は貴重な資料等を提供していただき，ま た，北海道大学工学部教授 井野 智工 学博士からは質疑について貴重な御助言をいただいた。 ここに厚く御礼を申し上げます。

\section{参考文献}

1）東 洋一, 小森清司：鉄筋コンクリート帯スラブの長期 たわみに関する実験的研究 (2), 日本建築学会大会講演 梗概集 (中国)，pp. 1837 1838，昭和 52 年 10 月

2）小柳光生著：鉄筋コンクリート床スラブの長期たわみに 関する研究，学位論文，p. 46，昭和 60 年 11 月

3）杉野目章, 井野 智ほか 3 名：使用荷重下における鉄筋 コンクリート梁のたわみについて, 日本建築学会北海道 支部研究報告集, No. 61, pp. 65 68, 昭和 63 年 3 月

4) ACI Comittee 435 : Proposed Reuistons by Comittee 435 to ACI Building Code and Commentary Prouisions on Deflections, ACI Journal, pp. 229 238, 1978, June

5）岩原昭次：長期設計荷重下における $\mathrm{RC}$ 造スラブの鉄筋 の抜出しに関する解析的研究, 日本建築学会構造系論文 報告集第 400 号, pp. 45 58, 1989 年 6 月

6) C. G Salmon, A. Fattah \& Saeed Mirge : Computetion of Deflection for Beams and One-Way Slaes SP 43-2, Deflection of Concrete Structures, pp. 15 53, 1974 
7）山田孝一郎：たわみ角法形式による骨組の弾塑性解法と その応用 (その 1 ), 日本建築学会論文報告集, 第 80 号, pp. $13 \sim 18$, 昭和 37 年 12 月

8）藤井 采, 森田司郎：異形鉄筋の付着応力-すべり関係に 関する考察，第二回 RC 構造の剪断問題に対する解析的 研究に関するコロキュム, pp. 37〜44, 1983.10

9）六車 熙, 森田司郎ほか：鋼とコンクリートの付着に関 する基礎的研究（付着応力分布について)-( II ), 日本建 築学会論文報告集, 第 132 号, pp. 1 6, 昭和 42 年 2 月

10）鈴木計夫，大野義照ほか：持続荷重下における異形鉄筋 とコンクリートの付着特性, セメント技術年報 40 , pp. 514 -517, 昭和 61 年

11）藤井 采, 森田司郎：異形鉄筋の付着割裂強度に関する 研究 第 2 報 付着割裂強度算定式の提案, 日本建築学 会論文報告集，第 324 号，pp. $45 \sim 53$, 昭和 58 年 2 月

12）村田二郎, 河合糺茲：引抜き試験による異形鉄筋の付着 強度に関する研究，土木学会論文集第 348 号 $/ \mathrm{V}-1$, pp. 113 122, 1984 年 8 月

13) 前出 2) : pp. 83 97

14）林静雄ほか：ひびわれ近傍における異形鉄筋とコンク リートの付着性状に関する実験研究，日本建築学会構造 系論文報告集第 348 号, pp. 86 97, 昭和 60 年 2 月

15）六車 熙, 森田司郎：鉄筋コンクリート梁の変形ときれ つ, 建築学会論文報告集第 90 号, pp. 13 18, 昭和 38 年 9 月

16）安藤雄平, 中田文四郎：鉄筋コンクリートスラブのクリー プ変形性状に関する実験研究（その1），日本住宅公団量 産試験場技術研究報告, No. 6, pp. 61 72, 昭和 503 月

17）中田文四郎ほか：鉄筋コンクリート大型スラブのクリー プ変形性状に関する実験研究（その1），配筋の違いによ る長期たわみと振動性状, 日本住宅公団総合試験場技術 研究報告, No. 10, pp. 59 72, 1979

18）松崎育弘ほか：鉄筋コンクリート造床スラブの長期たわ みに関する実験的研究（その 1$)$ ，鹿島建設技術研究所報 第 27 号, pp. 63 68, 昭和 54 年 6 月

19）山本俊彦ほか：若材令で過荷重を受けた RC スラブの長 期たわみ，東急建設技術研究所報 No. 8, pp. 85 92, 昭 和 57 年
20）小柳光生ほか：床スラブの長期たわみに関する研究，コ ンクリート工学 No. 9, pp. 115 124, Vol. 21, 1983

21）岩原昭次：両端固定鉄笳コンクリート造一方向床スラブ の長期曲げ性状，コンクリート工学年次論文報告集 9-2, pp. $615 \sim 620, .1987$

22）岩原昭次：ひび割れを入れた鉄筋コンクリート床スラブ の長期曲げ性状に関する研究 (その 3 ), 日本建築学会中 国· 九州支部研究報告第 7 号, pp. 289 292, 昭和 62 年 3 月

23）岩原昭次：鉄筋コンクリート床スラブの長期たわみ計算 法に関する研究 (その1. ひび割れを生じた一方向スラブ の瞬時たわみの解析法), 日本建築学会大会学術講演梗概 集, 構造 II, pp. 265 266，1989 年 10 月

24）小倉桂治ほか 4 名：RC スラブ長期たわみに関する研究 その 1, 日本建築学会学術講演梗概集, pp. 1497 1498, 昭和 53 年 9 月

注

1）表一 2 に示す試験体は，既往の実験資料において，載荷 とともにひび割れを生じた一方向スラブを，一部を除い て，ほとんど載せている。除いた実験資料は小倉ほかに よるもの ${ }^{24}$ であり，この小倉ほかの試験体は支保工撤去 と同時に端部にひび割れを生じており, 載荷前の乾燥収 縮による拘束ひずみの影響が顕著である。そのため, 乾 燥収縮の影響が考慮されていない本定式化による計算方 法では瞬時曲げ性状をより適確に評価できないと考え， 本論文では比較の対象から除いた。なおこのようなク リープや乾燥収縮を考虑する必要がある試験体の曲げ性 状については次報以後で述べる。

2）このような考察には注意を要する。我が国の一方向スラ ブに関する長期たわみ実験結果では, ACI 435 委員会推 奖式による計算值は長期たわみを過小評価することが知 られている。また，その主な影響は鉄筋の抜出しによる ことであることも知られている。しかしながら，ここで の考察は，瞬時たわみに限定しており，この瞬時たわみ に限っていうならば，本文のような考察ができる。

(1990 年 3 月 5 日原稿受理, 1990 年 6 月 25 日採用決定) 